\title{
Feminist Perspective in the Novel of Vikram Seth's A Suitable Boy
}

\author{
Hari Lal Kori \\ Research Scholar \\ Department of English and Other Foreign Languages \\ Dr. Shakuntala Misra National Rehabilitation University \\ Lucknow, Utter Pradesh, India
}

Dr. Vipin Kumar Pandey

Head of Department

Department of English and Other Foreign Languages

Dr. ShakuntalaMisra National Rehabilitation University

Lucknow, Utter Pradesh, India

h.lalpuneet8@gmail.com

\begin{abstract}
Men and women are the two best creation of nature. She has provided both equal rights but it is man who is too clever and has full control over woman. From a very long time he has limited her freedom and rights. That is why, they have been victims of inequality and exploitation for a very long time. The society which is of traditional mindset believes that a woman should live in boundary wall, give birth to children and to look after them. Most of the religions of the world emphasize that women should be subordinate to and dependent on men. In childhood they should be in take care of father, in youth by her husband and in old age by her sons. The Hindu philosophy, the religious books of Hindu as the Vedas, the Bhagavad-Gita, the Muslims the Christians and others also have same views about the
\end{abstract}


position of women in the society. All of them impose on women strict rules of discipline and prohibit them from the rights equal to men. The women's position in the family has been that of a servile creature, a playing thing an object of lust and pleasures. Commenting on the position of females in the society Shantha Krishnaswany Writes :

"She is a creature who as a child is sold of to stranger for a bridal price or when she grows-up serves as supplier of dowry for her husband's family or who as a widow in a final act of obliteration immolates herself on her husband's funeral pyre to be acclaimed as 'Sati-Savitri' as an immortal."

In this way, they had to live and suffer for a long period in a traditional standpoint and male dominated society. But change is the law of nature. Old things change, yielding to new. One thing can not last for a long time. There is also a proverb that 'there is delay in God's house but not darkness. Raja Ram Mohan Roy, Ishwar Chandra VidyaSagar, BadruddinTaiyab, DhondoKeshavKarve and so many social reformers came on the stage and raised their voice against the suppression, pangs, exploitation, disparity and subjection of women of the society. SavitribaiPhule, a social reformer and educationalist of Maharashtra established a school for the first time in India for girls. She is always remembered as the first woman teacher of India who did her best for the betterment of the women. Mary Wollstonecraft, Simone de Beauvoir, ElainShawlter, Virgina Woolf and others are also some name in the history, that can never be forgotten in life. The women of present time who are living happily, with respect and with their rights are very much indebted to them.

After the Independence in India the Indian government also promoted education towards building a better society. The Constitution of India which was introduced in 1950, also included so many crucial provisions for women welfare as well as for their empowerment. Women's studies and women's movement also came into existence and did their best for the welfare of women community. The women who are writing the novels or 
other genre of literature at present time are primarily focusing on the women's welfare, respect and their empowerment. Anita Desai, ShashiDeshpande, KamlaMarkandaya, BhartiMukharjee, Shobha De, NayantaraSahagal and others are some renowned name in Indian English literature who have secured their name and fame in the literary world. At present time they are writing novels. R.K. Narayan and Vikram Seth are also world-wide recognised for their writings. All these male and female writers who are advocating for the welfare, empowerment, equality and rights of women community are known and famous as a feminist. Feminist perspective came into prominence after the tireless efforts of the abovementioned and others.

The present paper will endeavour to discuss the presentation of women in A Suitable Boy, a bulkiest novel of Vikram Seth. He is a social writer of present day. He has written unique novels. They are not alike and have dissimilarity. In his novel A Suitable Boy, he has presented women characters form every filed. They are real and perform their role successfully.

Keywords: Impose, feminist, perspective, dominated, suppression, disparity, welfare, empowerment, pangs.

Vikram Seth is one of the most significant novelists in Indian English literature of present time. He is famous not only as a novelist but also as a travel writer, librettist, children's writer, a biographer as well as a memoirist. With the insolubility and depth of his work as well as considerable achievements in prose as well as in verse, Seth has proved that he is master in English Language. He was born on 20 June, 1952 in Calcutta of west Bengal in India. His father was Prem Seth who was an executive in a Bata India Limited shoe company. He migrated during his service period from one place to other. He could not stay with his family. Leila Seth, the first woman judge in Delhi High-Court was his mother. After sometime she became the chief justice of a state High Court at Simla. She studied law in 
London while pregnant with her second son and came first in her bar examination conducted one week after her delivery. Shantum is his younger brother who is a Buddhist and sister Aradhana is a film-maker, married to an Austrian diplomat. She worked in populer movies of Deepa Mehta's 'Earth and Fire'. His mother Leila Seth has discloses in her memoir 'On Balance' that most of the characters of the novel A Suitable Boy are amalgam butHaresh who works in a leather factory is a portrait of her husband Prem Seth After his greatness there is a great contribution of his parents. He was very much influenced by his parents. His father being a businessman had no time and interest in arts. But his mother Leila Seth was a learned woman and interested in poetry. She motivated Seth to write poetry.

Vikram Seth received his education at various places. He got his early education in a public school at Dehradun. He took his B.A. degree from Corpus Christi College, Oxford and enrolled himself in Stanford University in California, U.S.A. for Ph.D. He could not complete his research work. Then he went to China to join Nanjin University during the year 1980-82 to pursue his doctorate. Seeing the talent of Vikram Seth his teacher Timothy Steele encouraged him to write and supported him. The result was that Vikram Seth became a creative writer.

For his education he had to go at various places. He came into contact with the people of different religions, castes, cultures and geographical background. He lived in Asia, America, China, London, Veinna and Venice and achieved a lot of experience. His world wide travel has given him the great advantage of a wider exposer of life and communication across cultural background-Indian, European, Chinese and American. During this period he learnt many foreign languages besides English. He learnt Welsh, German, French, Mandarin, Urdu and Hindi. He is famous in the realm of literary world as a novelist but he himself has categorised as a poet first and novelist second. 
Vikram Seth, being a versatile writer, has written three novels. All these novels have their peculiar quality and is absolutely apart from one another. They differ in theme and technique with one another. The readers are attracted for their unique features. The Golden Gate his first novel is written in verse. It gives him credit of being first Indian novelist who wrote it in verse form. For this novel Seth was given the Sahitya Akademi Award in the year 1988. He has used rhyming tetrameter sonnet in this novel. It consists of 594 sonnets written in iambic tetrameter. The novel has five main characters. All of them are inter-connected. They are John Brown, Janet Hawakaya, Liz Dorati, Phil and Ed Dorati. Each comes from different background, different cities, different professions, yet they live in the same society.

An Equal Music is next novel of Vikram Seth. It was written in the year 1999. This novel is set in London with Western Classical Music as its background. This novel was awarded EMMA [BT Ethnic and Multi cultural Media Award] in 2001. It is a novel of musicians who dedicate their life for music. Music has been presented in the novel as a noble addiction. Michael Holme and Julia McNichol are main character of the novel who are lovers. Vikram Seth choose the theme of music and love as the main theme of the novel because Seth had very much interest in Music. He learnt music when he was a small boy. Seth has created very artistically and successfully the love story with the story of music and music lessons. According to Seth music can reduce our discomfort and by music anyone can pass his time. It alleviate the sufferings of life caused by unfulfilled love. It has not the romantic story of A Suitable Boy. An Equal Music can be compared with the novel of 'The Ground Beneath Her Feet' written by a notable and contemporary novelist of Vikram Seth, Salman Rushdie. This novel was also published in the same year in 1999 as well as has the same theme of music and love. It also portrays a modern story which has also symbolic parallel with the same Greek legend. In both novels the lovers are separated for ever. 
A Suitable Boy, with which the present paper is concerned was written in1993. This is only novel of Vikram Seth that is deeply rooted in Indian soil. His other two novels are related to the culture of California and London, Veinna and Venice. For this novel Vikram Seth achieved name and fame nationally and internationally. This novel also won others awards such as Commonwealth Writers Prize and WH Smith Literary Award in 1994. Simply as the little of the novel indicates that it deals with the theme the quest of a suitable boy for Lata, who is the protagonist of the novel and is younger daughter of Mrs. Rupa Mehra. She is too beautiful and completed her graduation from Brahmpur University. Now she is ready for marriage. Mrs. Rupa Mehra after Savitri and Pram marriage begins her search for a suitable bridegroom for Lata Mehra. She has three suitors. Kabir Durani, Amit Chatterjee and Haresh Khanna. Besides this theme, there are several sub- themes of the novel. It focuses on the experiences and entanglements of four moderately rich Indian families connected with one another through marriage or friendship at a period of time, when India was experiencing her post-independence turbulences. This novel is chiefly about the religions and familial customs of India and her people with the numerous characters serving as tools to illustrate the veracity of the customs. It has 19 section with sub-sections and wellcrafted. It has monumental length of 1349 pages. The novel moves around Mrs. RupaMehra's search of a suitable bridegroom for Lata her younger daughter. The narration centres around the story of four elite families- the Mehras, the chatterjees, the kapoors and the khan family. It presents the panorama of India after independence. Seth is very clever in story creating. He has managed very skilfully and artistically to interweave all the larger theme of political, social and religious conflict. In presenting the veracity of Indian life he has followed the traditional mode of novel writing. The veracity presented in the novel is social realism. He as a realist and social writer has delineated the real picture of 1950 s when the process of nation building was taking place under the leadership of our first prime minister Pt. JawaharLal 
Nehru. Seth was very much influenced with JawaharLal Nehru. That is why this novel is also known as Nehruviannovel.On the basis of its length the novel is regarded as longest novel published in England since Richardson's Clarissa and longer than Tolstoy's War and Peace. To make it great and relevant Seth has included four elite families of the then society. All these families and the family of the Mehras, the Kapoors, the Chattejees and the fourth family of the Khans. All these are interconnected to each other by marriage or friendship. Minimum four or five characters are seen in a family who in one way or the other experience a series of turbulent emotions, which slowly season them towards life and its adversities. Besides all the above noted families, Seth has introduced in the novel a lot of other characters from across religion, language and caste. To make the novel absolutely Indian some community stereotypes like money minded Marwadi businessman, the anglicisedParsis, and the professors from South Indian are presented.

The novel A Suitable Boy has a unique feature, that attracts our attention. It is its beginning with wedding ceremony of Mrs. Rupa Mehra's elder daughter Savita Mehra with a political family's son Pran, elder son of Mr. Mahesh Kapoor and ending also with the wedding ceremony of Lata Mehra the younger daughter of Mrs. Rupa Mehra and Haresh Khanna who does not belong to an elite family. To make the novel interesting and to attract the readers Seth has introduced the wedding ceremony and aspiration of a mother to find a suitable bridegroom for her younger daughter LataMehra but his primary focus is on the issues of the society of 1950 s after post independence such as, parliamentary speeches, the loss of partition, the zamidari abolition bill, communal riots, tension of the Hindu-Muslims, the flavour of the first India's general election of 1952, the scandalously living style of upperclass society, university life, the fading world of ghazals, arranged marriage, Independence, love, family, poverty, untouchability, politics, corruption in every walks of life, prostitution and culture. Thus it is apparent that the novel deals with so many sub-themes indirectly. 
The main objective of this paper is to draw attention towards the feminist standpoint of Vikram Seth. As far as, Vikram Seth's feminist perspective is concerned in his bulkiast novel A Suitable Boy, it would be articulate from the study of the women characters as well as their roles in the novel. As it has mentioned above that Vikram Seth has included four elite families of the Indian society and though, these families are inter-linked through marriage or friendship to each other but they are absolutely dissimilar in thinking and doing. Each family has four or more male and female members. All the female characters of the novel have played their role very skilfully. They represent, the other women of the Indian traditional and modern society.

Vikram Seth being, a social being of the society respects all women of the Indian society. I think, it would be pertinent to quote some lines from Sanskrit, Hindi and English language which are in my mind and they can prove Seth's feminist viewpoint to a great extent, as my deep study of the novel A Suitable Boy compels to quote them. There is a verse from Manusmriti that speaks about the respect of women :

"YatraNaryastupujyante, ramantetatraDevta,

Yatraitastu no pujyantesarvaastatrafalaahKriyaah."

Jayshankar Prasad, who was a prominent modern literary figure of Hindi language, perhaps he was not satisfied with the position of women in the society. Perhaps women did not get as much respect in society at that time as they should have. That is why, he wrote the lines in their respect in his 'Kamayni' :

"NaritumKevalShraddha ho,

Vishvasrasjat nag, pag-tal me

PiyushSrotsibahakaro,

Jivankesundarsamtal me". 
Feminist viewpoint of Vikram Seth discloses it that he was influenced much from the above quoted lines as well as of their composers.

My deep study of the novel discloses that there are so many female characters in the novel 'A Suitable Boy'. Vikram Seth is in the favour of all-round development of the women. He has emphasised on the good care and good education. He is of the opinion that no any family, society or nation can progress in true sense until it renounces discrimination, humiliation or inferiority towards women of the society. Therefore, they should be given all the sources for all round-development. They should have good care in childhood, good education as well as good respect.

In the novel we meet with a lot of feme charaters. In the Mehra family there are Mrs. Rupa Mehra who is a widow woman and guardian (mother and father both) of Mehra's young generation Arun, Varun, Aparna, Meenakshi, Lata and Savita, in the Kapoor family Mrs. old Tondon, Mrs. Mahesh Kapoor, Veena are seen, in the Chatterjee family of Calcutta. Mrs. Chatterjee, Meenakshi and Kakoli are feme members who are seen completely immersed in western culture and are anglicized and in the last family the Khans Begum Abida Khan and Zainab are seen as female members. Besides, all the above mentioned woman characters in the novel there are other feme characters who also play a crucial role in the novel. Malti who is active in politics is Lata's best friend. She always inspires her, whenever Lata is worried. Kalpna is next feme character who performs her role as a best match maker to Haresh Khanna. Saeeda Bai is ghazal singer. She attracts towards Mr. Maan Kapoor as well as Raja of Marh.

Mrs.RupaMehra who is mother of Savita and Lata and mother-in-law of Meenakshi plays her role well in the novel. She is introduced in the very beginning and opening of the novel at the time of weddding ceremony of her elder daughter Savita with PranKapoor who is 
a lecturer of English in Brahmpur University when she asks her younger daughter Lata if she would like a boy whom she selects for her bridegroom. She asks firmly with Lata :

"You too will Marry a boy I choose".

Mrs. RupaMehra can do all things, what a man can do. Her husband RaghubirMehra is not now but she fulfils all desires of her children. She does not allow her husband to miss the deficiency. She goes to all the fictious citieis like Kanpur, Delhi, Varanasi, Agra in search of a suitable boy for Lata. She posses all the qualities of men. At the wedding time of Savita all the people were doing namaste to her. She was feeling well. Seth presents thus :-

"Several guests were indeed doing namaste to Mrs. RupaMehra and smiling at her; the cream of Brahmpur society, she was topleased to note".

LataMehra, the protagonist of the novel, about whom the whole novel takes a round, the first sentence of the novel is related to whom has well adorned with all those qualities, that a woman needs by Vikram Seth. She is attractive, an obedient, a graduate from Brahmpur University. She is an ideal daughter. She never crosses the boundary line drawn by her mother. Being adolescent, she controls over herself. Although she is in love with Kabir Durani but her conscience never allows her to break the belief of her mother. She is always afraid of her mother and she never wants to do anything that would make angry her. When she comes to know from Malti that Kabir as a Muslim, her immediate reaction is that it would distress her mother. She is a brilliant and clever girl. She rejects Amit also and finally marries with Haresh Khanna.

Savita is elder daughter of Mrs. Rupa Mehra. She lives very peacefully after marriage with Pran. She has a daughter named Uma. Seth presents in the novel the best pair of her with Pran. She has been presented as a good daughter, as a good wife as a good mother and as a good daughter-in-law. She loves her sister Lata very much. Whenever Lata is worried she consoles her : 
"Life is merely froth and bubble.

Two things stand like stone.

Kindness in another's trouble,

Courage in our own".

She tries her best to make understand about love and marriage. Here it is seen that Seth has presented her as best example of the married pair.

Begum Abida Khan is another feme character of the novel. She is from the Khans family who were Zamindars. She is an MLA and Seth has presented her as a firebrand of the legislature. She is against traditional mindset of Muslim community. She opposes the purdah system and to remain in the zenana quarter for always. When her husband died, she left Baitar House and settled in other small house near legislative assembly. She never cares for the criticism of the old zenana's woman. She is MLA from Democratic Party and speaks boldly in the favour of Zamindars and opposes ZamindariAboliion Bill that would cause of the poverty and unemployment. Her speech of assembly is noteworthy :

"I would like to say on behalf of myself and the Democratic Party that the advice given by the pious and honourable Chief Minister to the Zamindars that they should maintain good relations with their tenants - is very valuable advice, and I thank firm for it. But we would have maintained such excellent relations anyway regardless of his excellent advice and regardless of the passage of this bill - this bill which will force so many people into poverty and unemployment, which will utterly destroy the economy and culture of this province, and which will at the same time grant not the least benefit to those who!

She does not only resist the purdah system of the society but also the teen talaq. She is champion of Muslim Women's community. MaltiTrivedi is another feme character, who is 
Lata's best friend. She is among the few girl students in a medical college of five hundred boys, having opted for a professional course unlike Lata who remains a student of English Literature. She participates in political meetings and is an active member of Socialist Party. Malti is akin Lata without father. Her mother is of open mind. She is different to a great extent, to Mrs. RupaMehra in nature. She allows to her daughters to choose their husbands. They live freely, they are not victim of patriarchy system.

Maggu Gopal who is a Magical Masseur of Pran Kapoor, has been presented by Vikram Seth speaking with Pan in the favour of women and need of them in our life. While he is messaging Pran tells about the need of a woman in life. He gives example of Napoleon who became great for his wife Josephine had supported him. For a success in life a man needs a woman. Every great men of the history had been supported by their wives. The lines in which Maggu is praising women should be quote here :

"Behind every successful man is a women. Behind Mr. Napoleon there was Josephine. Not that you have to be married. I do not believe it. In fact, I predict that you have had auspicious women in your life before and will continue to after Marriage (865 ASB).

In the ancient time in our country women had full respect and honour. But after sometime they lost it. They lost their freedom, but inside the boundary wall, and became victim of inequality and atrocity. The victorian poet Alfred Lord Tennyson in his poem 'The Princess' writes that a woman should live inside the house because it is a safe place for her. She should do all the homely works. There is no need to go her out of house. The lines are quotable :

"Man for the field and woman for the hearth :

Man for the sword and for the needle she :

Man with the head and woman with the heart : 
Man to command and woman to obey;

All else confusion".

Vikram Seth who thinks for the betterment of the women of the Indian society adocates for the rights of women in the novel. He is against the inequality, atrocity, dishonour and exploitation of women community in the male dominated society. He speaks in the favour of women Malti who is active in Socialist Party calls for the honour of women. She wants back the respect and the honour that were for her in the ancient time. Seth speaks through her mouth :

"The time has come when woman must be restored to the status she occupied in ancient India : we must combine the best of the past and the present, of the West and the East".

There is another woman who disparages the domestic confinement, transgrasses the feminine bounds and gets in the male domain. She is IlaChattopadhyay who is related to the Chatterjees and has pursued an academic career in spite of strong pressure from her family to give it up.

Thus, by the 126erusal of the above mentioned it is apparent that Vikram Seth has feminist perspective in his novel A Suitable Boy. Like other feminist he speaks in the favour of women's right, equality, atrocity, empowerment and all kinds of (social, cultural, economical and political) freedom. He wants that the government should provide all kinds of facilities to all women for the betterment of the family, society and the nation 


\section{Works Cited:}

Seth, Vikram, A Suitable Boy, Viking Penguin India, 1993.

Sinha, Prerna, Vikram Seth : The Suitable Writer : A Critical Response Creative Books, 2007.

Prasad, Murari, Vikram Seth's A Suitable Boy, An Anthology of Recent Criticism, Pencraft International, 2005.

Singh, Pramod Kumar, Major Indo-English Novelists and Novels : Jaipur : Sublime Publication, 2001.

Gupta, Roopali, Vikram Seth's Art : An Appraisal. New Delhi : Allantic Publishers and Distributors, 2005.

Majumdar, Maya. Social Status of Women in India, New Delhi : Dominant 2004. 